\title{
METHODS OF DETERMINATION OF PARAMETERS OF WHEY WITH FOOD FIBERS
}

\author{
Sergii Tsygankov \\ Institute for Food Biotechnology and Genomics of NAS of Ukraine \\ 2 A Osypovskogo str., Kyiv, Ukraine, 04123 \\ tsygankov.iht@gmail.com \\ Olena Grek \\ Department of technology of milk and dairy product \\ National University of Food Technology \\ 68 Volodymyrska str., Kyiv, Ukraine, 03680 \\ grek.nupt@gmail.com \\ Olena Krasulya \\ Department of technology of milk and dairy product \\ National University of Food Technology \\ 68 Volodymyrska str., Kyiv, Ukraine, 03680 \\ olena_krasulya@ukr.net \\ Olena Onopriichuk \\ Department of technology of milk and dairy product \\ National University of Food Technology \\ 68 Volodymyrska str., Kyiv, Ukraine, 03680 \\ olena.onopriychuk@gmail.com

\section{Larisa Chubenko} \\ Department of technology of milk and dairy product \\ National University of Food Technology \\ 68 Volodymyrska str., Kyiv, Ukraine, 03680 \\ lorkachub@gmail.com

\section{Oleksandr Savchenko}

Department of technologies of meat, fish and marine products National University of Life and Environmental Sciences of Ukraine

15 Heroiv Oborony str., Kyiv, Ukraine, 03041

63savchenko@gmail.com

\section{Olha Snizhko}

Department of technologies of meat, fish and marine products National University of Life and Environmental Sciences of Ukraine

15 Heroiv Oborony str., Kyiv, Ukraine, 03041

snezhkoolha@gmail.com

\section{Olena Ochkolyas}

Department of technologies of meat, fish and marine products National University of Life and Environmental Sciences of Ukraine 15 Heroiv Oborony str., Kyiv, Ukraine, 03041

lenokochkolyas@gmail.com 


\begin{abstract}
The article presents fixation methods of parameters of whey with food fibers for fermentation with lacto-fermentative Zygosaccharomyces lactis $868-K$ yeast for getting a non-alcoholic fermented beverage.

As a result of the analysis of conditions of preparation and introduction of food fibers - apple pectin in cellulose and orange Citri-Fi into whey, there were determined optimal parameters of the process of increasing viscosity of whey-vegetable mixtures.

The method of IR-spectroscopy fixed the influence of different forms of bonds of food fibers' moisture in mixtures with water and whey. There was revealed the continuous absorption of moisture of spectrums of samples with food fibers and apple pectin in cellulose in strips of 2668 and $2723 \mathrm{~cm}^{-1}$, that testifies to the presence of strong hydrogenous bonds and high concentration of a mobile proton and, as a result, the high sorption ability to water.

There were offered methods and gotten results of the analysis of the carbon dioxide content, amount of formed ethyl alcohol and yeast cells, allowing to determine rational conditions of fermentation of whey-vegetable wort of the increased viscosity. At fermentation using Zygosaccharomyces lactis $868-K$ race, the most intensive increment of yeast cells was observed before 30 hours of fermentation. There was established the rational temperature of fermentation of whey-vegetable wort with the increased viscosity$30 \ldots 32{ }^{\circ} \mathrm{C}$, at which the maximal accumulation of yeast cells $-70,5 \ldots .71,2 \mathrm{Mmln} / \mathrm{cm}^{3}$ and ethyl alcohol $0,69 \ldots 1,02 \%$ was observed.

The presented information was enough for grounding parameters of technological stages of whey fermented beverages with the high viscosity.

Keywords: whey, IR-spectrometry, full-facto experiment, fermentation, whey-vegetable wort of increased viscosity.

\title{
1. Introduction
}

Fermented beverages production is the one of rational ways of using whey that is an accessible form of correcting the human food status by enriching with physiological functional ingredients with the favorable influence on metabolism and immunity [1-3]. All non-alcoholic beverages including whey ones are refreshing products in the human everyday ration. Their food value is connected with providing the water balance and energy of the organism [4-6].

The problems that need scientific foundation at developing technologies of whey beverages with the increased viscosity are: choice of an available vegetable ingredient; regulation of its guaranteed content; rationalization of the production process [7-12].

Alternative ingredients of the vegetable generation for regulating the consistence of beverages can be dry concentrates of citrus plants- Citri-Fi (Fiberstar Inc., USA) - a series of natural improved food fibers. According to producer's information, their introduction in recipes of milk products positively influences not only their biological value, but also technological properties. Orange fibers have structure-creating and antioxidant properties $[13,14]$. Their introduction in recr ipes allows to stabilize viscosity characteristics, to enrich whey-based beverages with food fibers, accent the taste, widen the assortment. The special interest is caused by apple pectin in cellulose (APC), produced in Ukraine according to TC U 30335750.001-2000. It consists of extruded wheat bran (60\%), apple powder (38 \%), and pectin (2\%). The concentrate has solubility $(33,0 \pm 0,99) \%$, moisture-absorbing ability in water $-(90,0 \pm 2,70) \%$ and in whey, correspondingly, $-(84,0 \pm 2,52) \%$.

The aim of the work is to determine methods of studying whey-vegetable mixtures that allows to develop fermented beverages with the increased viscosity.

\section{Materials and Methods}

Apple pectin in cellulose was used for preparing whey with food fibers. The chemical composition of the apple powder is presented in Table 1 [15-18].

Citri-Fi 200 - is an orange food fiber, gotten of cellular tissues of dried pulp without using chemical reagents by mechanical processing. Citri-Fi 200 has the sanitary-epidemiological conclusion of HM of Ukraine [19]. Orange fibers by organoleptic parameters - a powder of the light-cream color with the neutral taste and smell with storage term 36 months. According to producers' data, «Citri-Fi 200» is able to absorb from 8 to 13 mass shares of water for 1 mass share of fiber, $\mathrm{pH}$ is $4,0-5,0$. The food value $100 \mathrm{~g}-224 \mathrm{kcal}$. The physical-chemical and microbiological parameters of orange food fibers «Citri-Fi 200» are presented in Table 2. 
Table 1

Chemical composition of the apple powder

\begin{tabular}{cc}
\hline Parameter & Chemical composition of 100g of product \\
\hline Mass share of moisture, \% & 6,0 \\
Mass share of sugars, \% & 48,7 \\
Including reducing ones & 40,9 \\
Saccharose & 7,8 \\
Mass share of organic acids (for apple acid) $\%$ & 5,0 \\
Mass share of cellulose, \% & 13,4 \\
Mass share of pectin substances, \% & 12,4 \\
Including soluble in water & 5,1 \\
Insoluble & 7,3 \\
Proteins, $\%$ & 6,7 \\
Fats, $\%$ & 6,8 \\
Mineral substances, $\%$ & \\
Potassium & 0,080 \\
Magnesium & 0,073 \\
Calcium & 0,320 \\
Phosphorus & 0,240 \\
Vitamins, mg & \\
Carotenoids & 0,80 \\
Ascorbic acid & 76,4
\end{tabular}

Table 2

Parameters of «Citri-Fi 200»

\begin{tabular}{cccc}
\hline Physical-chemical parameters & \multicolumn{2}{c}{ Microbiological parameters } \\
\hline Total fat, \% & 1,08 & Number of bacteria, CFU/g & $<10^{5}$ \\
Total carbohydrates, \% & 82,55 & Yeast, mold, in $1 \mathrm{~g}$ & $<500$ \\
Total amount of cellulose, \%: & 75,3 & & \\
soluble & 39,6 & Coliform bacillus, in 1 g & \\
insoluble & 35,7 & & negatively \\
Sugar, $\%$ & 5,38 & Salmonella, in $1 \mathrm{~g}$ & $<10$
\end{tabular}

Samples of food fibers Citri-Fi were studied using an ultraviolet microscope (Axioskop 40, Carl Zeiss, Germany), equipped by the optic system of the luminescent lighting and universal condenser (Fig. 1). It works in the magnification diapason from $\times 1$ to $\times 100$ with the possible fast change of light filters.

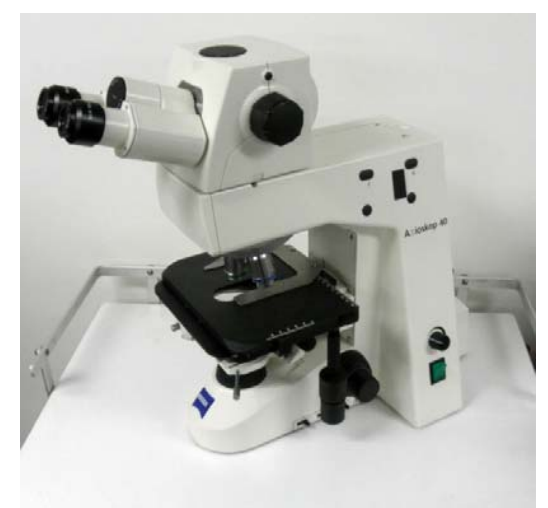

Fig. 1. Ultraviolet microscope Axioskop 40, Carl Zeiss 
For fixing transformations of dry Citri-Fi at swelling in whey, a dye Acridine Orange (BD Difco, China), was used.

For realizing the study, there were developed different mixtures, based on whey without vegetable ingredients (control) with following parameters: $(6,5 \pm 0,33) \%$ of dry substance, $(4,6 \pm 0,23) \%$ of lactose, $(1,3 \pm 0,07) \%$ of protein, $\mathrm{pH}(4,5 \pm 0,23)$, and also with APC and Citri-Fi.

At first APC was introduced in a whey share in amount of $20 \ldots 22 \%$, intermixed for $10 \ldots 15$ min and swelled at the temperature $35 \ldots 40{ }^{\circ} \mathrm{C}$. For preparing wort with the increased viscosity, the prepared whey-vegetable whey in amount of $10 \ldots 15 \%$ was introduced in the main whey volume at the temperature $50 \ldots 60{ }^{\circ} \mathrm{C}$ and intermixed for $8 \ldots 10 \mathrm{~min}$. After the thermal processing at the temperature $(74 \pm 2){ }^{\circ} \mathrm{C}$ and keeping for $15 \ldots 20 \mathrm{~s}$, wort was cooled to the fermentation temperature $(30 \pm 2){ }^{\circ} \mathrm{C}$. Wort based on whey with Citri-Fi was prepared at the same temperature regimes.

The control - whey without vegetable ingredients

After introducing lacto-fermenting yeast Zygosaccharomyces lactis 868 -K before fermentation, wort has the following initial parameters: content of dry substances $-8,5 \%$; concentration of reducing substances $-4,5 \%$; active acidity $-4,6$; yeast cells convcentration $-42 \mathrm{mln} / \mathrm{cm}^{3}$.

\section{IR-spectroscopy}

The method of IR-spectroscopy determined the influence of food fibers on forms of moisture bonds in mixtures. For that, there were prepared mixtures, based both on water and whey with orange food fibers and apple pectin in cellulose. The obtained samples were dried, comminuted, intermixed 1-2 g with 3-4 drops of pure vaseline oil (nuyol) to suspension.

Nuyol without additional strips in the area of absorbing water was used as an internal standard. The infrared spectrum of suspension was filmed by the method of crushed drop between windows KRS-5 on FTIR-spectrophotometer «Nexus», made by «Nicotel»,USA. Filming regime: scanning diapason $-400-4000 \mathrm{~cm}^{-1}$, number f scans in second -7 , scanning interval $-1 \mathrm{~cm}^{-1}$. The picture of FTIR-spectrophotometer «Nexus» is presented on Fig. 2.

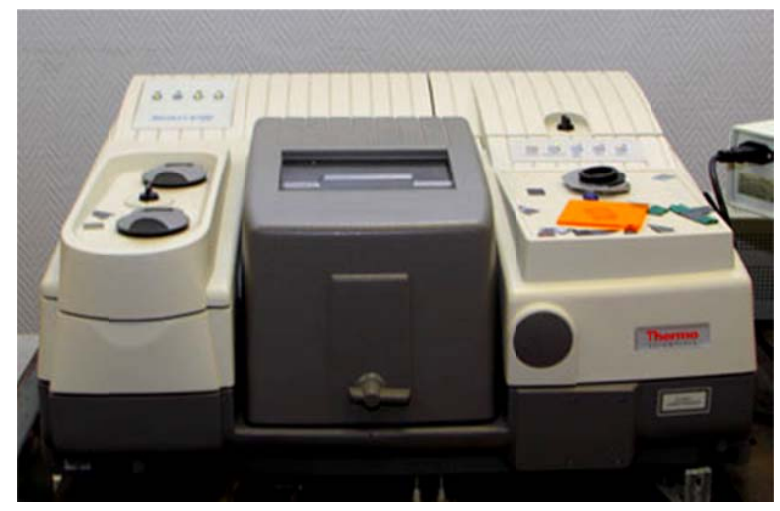

Fig. 2. FTIR-spectrophotometer «Nexus»

\section{Rheological studies}

The determination of the optimal composition for rationalizing technical conditions for getting a homogenous beverage with the increased viscosity was realized in two stages.

Whey-vegetable mixtures with different amounts of Citri-Fi - from 1 to $11 \%$ were produced at the first stage. For this aim food fibers were introduced in the whey share. This way of mixtures preparation allows to dissolve food fibers better and to intensify wort fermentation in further.

Viscosity was chosen as a main parameter that characterizes the optimal composition of the model mixture. Viscosity with the maximal value $30 \mathrm{~Pa} \cdot \mathrm{s}$ [20] determines the consistence and essentially influences fluidity of the whey-vegetable mixture. This parameter is important from the point of view of its further transportation and introduction in the whey main volume. It was taken into account at determining the optimal amount of food fibers, temperature and swelling duration.

The full-factor experiment was realized with data processing using the applied mathematical package MathCad 15. 
Whey-vegetable mixtures were studied. The native whey, heated to the temperature $(30 \pm 2){ }^{\circ} \mathrm{C}$ was added with orange fibers in amounts from 1 to $11 \%$. After that the mixture swelled for $5 . .15 \mathrm{~min}$ at the temperature from 20 to $40^{\circ} \mathrm{C}$.

The effective viscosity of the received model mixtures was measured using a viscosimeter «Rheotest II» (Labtech, Russian Federation). It uses the double-cylinder measuring system that allows to determine structural mechanical characteristics of the studied samples.

The measurement of the shear stress $\tau(\mathrm{Pa})$ was realized with changing gradients of the shear stress $\gamma$ in the diapason $0,33 \ldots 145,8 \mathrm{~s}^{-1}$ at the direct movement. Data of the viscosimeter indicated the maximal deflection angle of a pointer on the gage dial. The value of the shear stress (Pa) was calculated by the formula:

$$
\tau=Z \cdot a,
$$

where $\mathrm{Z}$ - cylinder constant, Pa.un of scale; $\alpha$ - measuring index.

Effective viscosity $(\mathrm{Pa} \cdot \mathrm{s})$ was calculated by the formula:

$$
\mathrm{n}_{\mathrm{ef}}=\frac{\tau}{\gamma}
$$

where $\gamma$-gradient of the hearing force, $\mathrm{s}^{-1}$.

The main aim of the second stage was to determine the optimal amount of the model whey-vegetable mixture, introduced in the main volume of whey for getting a fermented beverage, enriched with food fibers, saturated with carbon and so on.

The full-factor experiment was realized with the further data processing using the program package MathCAD 15. In sum there were produced fourteen different samples of whey-vegetable mixtures, later on subjected to fermentation with Zygosaccharomyces lactis 868-K.

The aforesaid samples were obtained as following: whey-vegetable mixtures, prepared according to the first stage, were added to the main whey share. The amount of food fibers in the prepared samples varied from 5 to $15 \%$. The mixing temperature was within $30 \ldots 60{ }^{\circ} \mathrm{C}$. Then the mixture was intermixed for $6-10 \mathrm{~min}$ then pasteurized at the temperature $(78 \pm 2){ }^{\circ} \mathrm{C}$ and kept for 2-3 min. The dynamic viscosity parameter in the prepared samples was determined using a viscosimeter of Heppler VH-2 (Standard-M, Ukraine). The dynamic viscosity coefficient was calculated by the formula:

$$
\eta=K \cdot\left(\rho-\rho_{0}\right) \cdot \tau
$$

where $\eta$ - dynamic viscosity, $10^{-3} \mathrm{~Pa} \cdot \mathrm{s} ; \tau$ - time of the ball movement, s; $\rho$ - density of the ball material, $\mathrm{kg} / \mathrm{m}^{3} ; \rho_{0}$ - density of the studied product, $\mathrm{g} / \mathrm{cm}^{3} ; \mathrm{K}$ - ball constant, $\left(10^{-3} \mathrm{~Pa} \cdot \mathrm{s} \cdot \mathrm{cm}^{3} / \mathrm{g} \cdot \mathrm{s}\right)$.

At this stage of the experiment we studied beverages with different viscosity. The sample with the stabilizer Grindsted SB 251 (DuPont (Danisco), USA) (its composition: gelatin, starch, acetylated distarch adipate (E 1422), pectin, (E 440)) was chosen as a control. It has the stable dynamic viscosity at the level $(2,55 \pm 0,13) 10^{-3} \mathrm{~Pa} \cdot \mathrm{s}$. This parameter was used as a standard criterion for determining the optimal amount of the mixture and conditions of intermixing with the main whey volume.

\section{The analysis of fermentation parameters of whey-vegetable mixtures}

All samples, prepared as it was described above, were fermented at the first stage. The process was organized as following: immediately after pasteurization they were cooled to the temperature $30^{\circ} \mathrm{C}$, then each sample was added with lacto-fermenting yeast Zygosaccharomyces lactis $868-K$. This yeast culture was grown on stroke plates with whey wort in a thermostat at temperature $(30 \pm 2)^{\circ} \mathrm{C}$ during 24 hours. Then cells were transferred in the amount of $1 \cdot 10^{6} \mathrm{CFU} /$ $\mathrm{cm}^{3}$ of the medium in flasks with the volume $2 \mathrm{dm}^{3}$ with $1 \mathrm{dm}^{3}$ of sterile whey wort $(8 \%$ of dry substances). Yeast cultivation was realized on a rocker, at 220 turns/min during 24 hours at the temperature $(30 \pm 2){ }^{\circ} \mathrm{C}$. The grown biomass was separated in the cultural liquid, filtered on a vacuum-filter. 
The choice of Zygosaccharomyces lactis $868-K$ was substantiated by the fact that this type of microorganisms is rather effective for fermentation activity of wort, based on whey with food fibers (APC and Citri-Fi). Lacto-fermenting yeast Zygosaccharomyces lactis $868-\mathrm{K}$ is obtained from the museum of SI "Institute of food biotechnology and genomics", NAS, Ukraine (Kiev).

The change of activity of lacto-fermenting yeast in the process of fermentation of wort with the increased viscosity was determined by excreted carbon dioxide. The weight method was used.

The fermented whey-vegetable wort was distilled for determining the alcohol mass share in distillate. The total number of yeast cells with staining by Lugol's solution in $1 \mathrm{~cm}^{3}$ was determined by the direct calculation in Goryaev's chamber. Indications were taken each 6 hours of fermentation during 36 hours.

The statistical analysis of parameters of fermentation of wort with the increased viscosity

Data present the mean value of three independent experiments \pm SD. Statistical differences between experimental groups were assessed by the dispersion analysis (ANOVA) using the program package COSTAT (Cohort Software, CA, USA).

\section{Experimental procedures}

Using the full-factor experiment, there were established the optimal parameters for preparing whey-vegetable mixtures: Citri-Fi amount $-4 \ldots 5 \%$, intermixing duration $-10 \ldots 15$ min, swelling temperature $-30 \ldots 35^{\circ} \mathrm{C}$. There was also determined the rational amount of the whey-vegetable mixture as $10 \ldots 12,5 \%$ for introducing in the main whey volume. It is necessary to observe the regimes: temperature $-50 \ldots 60{ }^{\circ} \mathrm{C}$, intermixing duration $-8 \ldots 10 \mathrm{~min}$.

There were obtained IR-spectrums of transmission for dry whey (control), dry APC and Citri-Fi, and also, correspondingly, mixtures of food fibers APC and Citri-Fi with water and whey. The typical feature of compositional mixtures with Citri-Fi is a distinct increase of relative intensity of a strip $1741 \mathrm{~cm}^{1}$, typical for $\mathrm{H}^{+}$-form of the carboxyl group.

The appearance of the strips 2668 and $2723 \mathrm{~cm}^{-1}$ in dry samples of Citri-Fi and also Citri-Fi mixtures with water and whey may testify to the formation of strong $\mathrm{H}^{+}$-bonds of the bridge type and dissociated mobile proton. Spectral manifestations of such bonds are detected in the sample of the water mixture with orange food fibers (strip $2159 \mathrm{~cm}^{-1}$ ). The relative intensity of water strips is the most in the water mixture with Citri-Fi, where the salt form of the carboxyl group is fixed together with $\mathrm{H}^{+}$-form (strip $1534 \mathrm{~cm}^{-1}$ ).

The presented studies of IR-spectrums of transmission of APC Citri-Fi mixtures with water and whey testify to manifestations of distinct strips of spectral bonds in the area of valent fluctuations $\mathrm{C}=\mathrm{O}\left(1748 \mathrm{~cm}^{-1}\right), \mathrm{C}-\mathrm{O}\left(1151 \mathrm{~cm}^{-1}\right)$ of groups. Two strips $\mathrm{C}=\mathrm{O}$, and also $\mathrm{C}-\mathrm{O}$ and $\mathrm{OH}$ may testify to the presence of two types of carboxyl groups $\left(-\tilde{\mathrm{N}}_{\hat{\mathrm{I}}}\right)^{-}$.

The microphoto Citri-Fi 200, visualizing the open and soluble structure of cells of fibers, which links are able to bind the essential amount of liquid and to keep it, was obtained using autofluorescence. The picture indirectly confirms moisture-binding properties, declared by the producer.

The rational conditions of fermentation of wort with the yeast cells concentration $40 \mathrm{mln} / \mathrm{cm}^{3}$ of wort were determined by the aforesaid methods. The fermentation dynamics of whey-vegetable wort of the increased viscosity by indices of carbon dioxide emission was studied during 36 hours. The obtained values are presented on Fig. 3. For establishing the rational temperature of fermentation, there was determined the amount of accumulated yeast cells in wort with the increased viscosity depending on temperature $\left(24 \ldots 36^{\circ} \mathrm{C}\right)$. The results of the experimental studies are presented on Fig. 4.

According to the data, presented on Fig. 3, the maximal accumulation of $\mathrm{CO}_{2}$ was observed in 30 hours of cultivation $(1,2$ and $1,45 \mathrm{~g} / 100 \mathrm{ml}$ at fermentation of wort with apple pectin in cellulose and in control, respectively). Then fermentation activity of yeast decreases because of decreasing the amount of nutrients. At the additional fermentation almost all monosaccharides were utilized by yeast cells.

According to the data (Fig. 4), the maximal accumulation of yeast cells $-70,5 \ldots 71,2 \mathrm{mln} / \mathrm{cm}^{3}$ is observed at using Zygosaccharomyces lactis 868-K yeast at the temperature of whey-vegetable wort 
fermentation $30 \ldots 32{ }^{\circ} \mathrm{C}$. The further increase or decrease of the temperature diminishes this index that testifies to the decrease of enzymes' activity in cells. There was also determined the amount of ethyl alcohol in whey-vegetable wort, observed as $1,02 \%$ in the control sample at the temperature $32{ }^{\circ} \mathrm{C}$. This parameter was fixed in whey with APC at the level 0,69\%. According to the requirements of normative documents for alcohol-free beverages (SSTU 4069:2002), the amount of ethyl alcohol no more than $1,2 \%$ of a product is allowed. The obtained results are agreed and may be used for realizing the technology of fermented whey beverages with the increased viscosity.

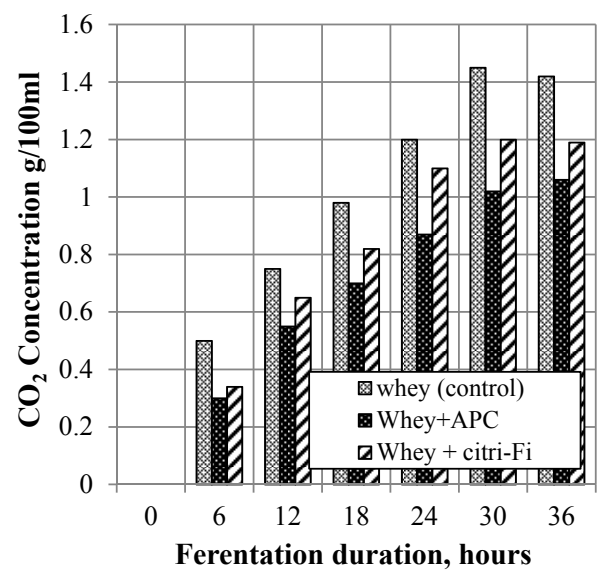

Fig. 3. Dynamics of carbon dioxide accumulation in whey-vegetable wort

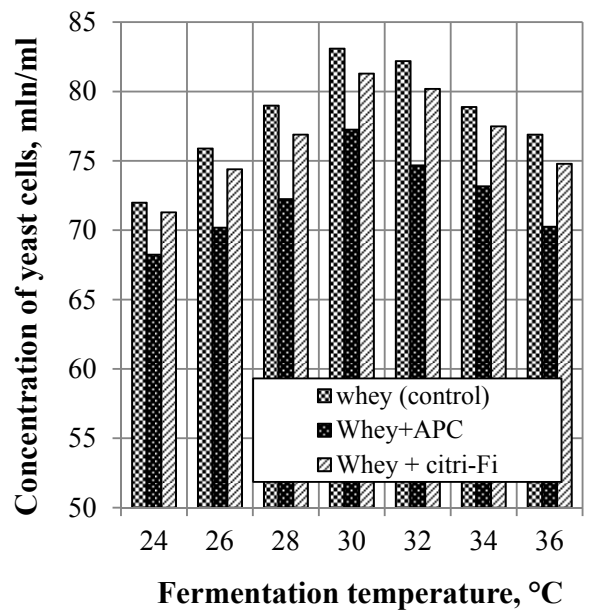

Fig. 4. Change of yeast cells concentration depending on fermentation temperature in whey-vegetable wort

\section{Conclusions}

The method of IR-spectroscopy determined the high moisture-binding abilities of the food fibers Citri-Fiand APC, found by the continuous absorption of IR-spectrums of water strips in the fluctuation zone 2668 and $2723 \mathrm{~cm}^{-1}$ in whey.

The full-factor experiment with data processing using the applied mathematical package MathCad 15 allowed to determine the optimal parameters of the process of increasing viscosity of whey-vegetable mixtures: Citri-Fi amount $-4 \ldots 5 \%$, intermixing duration $-10 \ldots 15$ min, swelling temperature $-30 \ldots 35^{\circ} \mathrm{C}$. There was also determined the rational amount of the whey-vegetable mixture $(10 \ldots 12,5 \%)$, at the following regimes of introducing in the main whey volume: temperature- $50 \ldots 60{ }^{\circ} \mathrm{C}$, intermixing duration $-8 \ldots 10 \mathrm{~min}$.

The presented results are the base for determining the parameters of fermentation of whey beverages with vegetable ingredients. The amount of ethanol in the control sample at the temperature $32{ }^{\circ} \mathrm{C}$ was $1,02 \%$. And for whey and Citri-Fi this index reached $0,79 \%$. The presence of 
Citri-Fi in wort, as it has been already noted, results in decreasing yeast activity and, as a result, decreasing the ethyl alcohol amount.

The presented information is recommended to be used for substantiating the parameters of stages of the technology of whey fermented beverages with the increased viscosity.

\section{References}

[1] Jelicic, I., Bozanic, R., Tratnik, L. (2008). Whey based beverages - new generation of dairy products. Mljekarstvo, 58 (3), 257-274.

[2] Khramtsov, A. G. (2011). The phenomenon of milk whey. Saint Petersburg: Profession, 804.

[3] Bulatovic, M., Rakin, M., Mojovic, L., Nikolic, S., Vukasinovic-Sekulic, M., Djukic-Vukovic, A. (2012). Whey as a raw material for the production of functional beverages. Hemijska Industrija, 66 (4), 567-579. doi: 10.2298/hemind111124009b

[4] Chumburydze, T. (2010). Polza napitkov [Good drinks]. Osnovi bezopasnogo i sbalansirovannogo pitania [Basics safe and balanced diet]. Kyiv, 18-19.

[5] Ostroumov, L. A., Razumnikova, I. S., Frolov, S. V. (2008). Ispolzovanie molochnoy sivorotky v tehnologii napitkov [Use of whey beverage technology]. Sovremennie naukoemkie tehnologii pererabotki sira i proizvodstva produktov pitania: sostoyanie, problemi i perspektivi razvitiya [Modern high technology processe ing of raw materials and food production: status, problems and prospects of development]. Omsk: OmEI, 72-73.

[6] Suhih, S. A., Frolov, S. V. (2008). Tehnologia toniziruischih napitkov na osnove vtorichnogo molochnogo sirja [Technology tonics based on the secondary raw milk]. Dostizhrnia nauki i tehniki APK [Advances in science and technology APC], 5, 54-55.

[7] Evdokimov, I. A., Volodin, D. N. (2016). Sovremennoe sostoyanie i perspektivy pererabotki molochnoy syvorotki. Pererabotka moloka, 8, 10-13.

[8] Hramtsov, A. G., Nesterenko, P. G., Evdokimov, I. A., Ryabtseva, S. A., Lodygin, A. D. (2014). Al’ternativnye varianty promyshlennoy pererabotki molochnoy syvorotki. Molochnaya promyshlennost', 11, 44-48.

[9] Jelen, P. (2011). Whey processing. Utilization and Products. Encyclopedia of Dairy Sciences (Second Edition), 731-737.

[10] Kumar, N., Vandna, Hati, S. (2015). Fermented and non fermented whey beverages. Beverage $\&$ food world, 42 (4), 25-31.

[11] Chavan, R. S., Shraddha, R. C., Kumar, A., Nalawade, T. (2015). Whey based beverage: its functionality, formulations, health benefits and applications. Journal of Food Processing \& Technology, 6 (10), 495. doi: 10.4172/2157-7110.1000495

[12] Suhih, S. A., Frolov, S. V. (2008). Technology of tonics based on the secondary raw milk. Achievements of Science and Technology of AIC, 5, 54-55.

[13] Shestopalova, N. E. (2010). Apelsinovie pischevie volokna Citri-Fi v sbivnih masah [Orange fiber Citri-Fi in whipped masah]. Konditerskoe i hlebopekarskoe proizvodstvo [Confectionery and bakery production], 11, 28-29.

[14] Grek, E., Krasulia, E. (2013). Issledovanie vliyania pischevih volokon na formu svyazi vlagi v smesiah s molochnoi sivorotkoi [Study of dietary fiber impact on moisture binding forms in mixtures conf taining milk whey]. Maisto chemija ir technologija [Food chemistry and technology]. Kaunas, 47 (1), 15-21.

[15] Perfylova, O., Mytrofyn, M. (2008). Using powder of vegetables and fruits with expansion assortment of bakery products. Achievements of science and technics Agro-Industrial Complex, 8, 48-50.

[16] Krokida, M. K., Philippopoulos, C. (2006). Volatility of apples during air and freeze drying. Journal of Food Engineering, 73 (2), 135-141. doi: 10.1016/j.jfoodeng.2005.01.012

[17] Kohajdova, Z., Karovicova, J., Simkova, S. (2009). Use of Apple fibre in bakery products. Acta fytotechnica et zootechnica, 12, 286-290.

[18] Colin-Henrion, M., Mehinagic, E., Renard, C. M. G. C., Richomme, P., Jourjon, F. (2009). From apple to applesauce: Processing effects on dietary fibres and cell wall polysaccharides. Food Chemistry, 117 (2), 254-260. doi: 10.1016/j.foodchem.2009.03.109

[19] Zaklyuchenie gosudarstvennoy sanitarno-epidemiologicheskoy ekspertizy (2009). No. 05.03.0203/507351.

[20] Kosoj, V. D., Dunchenko, N. I., Merculov, M. U. (2010). Dairy rheology. Moscow: DeLi Print, 826. 